\title{
National emissions ceilings for 2005 and 2010 and their impact on Portuguese air quality
}

\author{
A. I. Miranda ${ }^{1}$, A. Monteiro ${ }^{1}$, M. Lopes ${ }^{1}$, C. Borrego \& A. T. Perez ${ }^{2}$ \\ ${ }^{1}$ Department of Environment and Planning, \\ University of Aveiro, Portugal \\ ${ }^{2}$ National Institute for the Environment, Lisbon, Portugal
}

\begin{abstract}
Accordingly to the EU Directive 2001/81/EC, all the Member States should develop and implement a national programme to reduce the emissions of acidifying gases, in order to reach, before 2010, the National Emission Ceilings (NEC). In this context, Portugal has developed technical studies aiming to set up a reference scenario until 2010 and to evaluate the compliance of the emission ceilings established to this target year. In addition to this reference scenario, high and low emission reduction scenarios were also defined. Notwithstanding 2010 scenarios, the same procedure was applied to 2005 and two reduction scenarios, high and low, were considered. This works intends to evaluate the impacts of these national emission reduction scenarios on the air quality in Portugal, verifying the fulfilment of the air quality thresholds for 2005 and 2010. A numerical modelling system was applied over Portugal to these hypothetical situations and results were compared to those from an application to a baseline year - 2001. The selected numerical system is the 3D chemistry-transport model CHIMERE, which uses data from the European Centre for Medium Range Weather Forecast as meteorological input. Assuming the 2001 simulated meteorological conditions, the results point towards a reasonable improvement of the air quality over Portugal. It forecasted a significant decrease of ozone levels, especially in the downwind urban areas of Lisbon and Porto. These results strengthen the importance of including the NEC emission scenarios into the national strategy for air quality management.
\end{abstract}

Keywords: emissions scenarios, legislation, air quality impact. 


\section{Introduction}

At the Community level, the "National Emission Ceilings" (NEC) Directive was adopted in 2001 in order to limit the negative environmental impacts of acidification, eutrophication and ground-level ozone [1]. This Directive obliges each Member State to develop and to implement a strategical National Program (PTEN) to comply with the emissions ceilings until 2010 for the most critical acidifying air pollutants, namely sulphur dioxide $\left(\mathrm{SO}_{2}\right)$, nitrogen oxides $\left(\mathrm{NO}_{\mathrm{x}}\right)$, non-methane volatile organic compounds (NMVOC) and ammonia $\left(\mathrm{NH}_{3}\right)$, responsible for baneful effects on environment. These NEC have been established in a series of Protocols under the United Nations Convention on Long-Range Trans-boundary Air Pollution (CLRTAP), culminating in 1999 with the adoption of the Gothenburg Protocol [2].

In order to analyse the efficiency of the national programmes it is important to evaluate their effects on the air quality, taking into account the national reduction measures. Atmospheric modelling techniques constitute helpful tools for this air quality assessment. The main objective of this study was to verify the fulfilment of the air quality limit values for 2005 and 2010 considering the National Emission Ceiling Scenarios. Photochemical simulations for Continental Portugal were carried out first to the 2001 baseline year, using the CHIMERE chemistry transport model forced by the European Centre for Medium-Range Weather Forecasts (ECMWF) meteorological data, and secondly to the 2005 and 2010 emissions scenarios.

\section{Emission ceilings scenarios}

The numerical values for the 2010 emission ceilings for the individual Member States were based on the findings of extensive analysis using the 'Regional Air Pollution Information and Simulation' (RAINS) model developed by the International Institute for Applied Systems Analysis (IIASA) [3]. This model was applied to find the internationally least-cost allocation of emission control measures. In what concerns Portugal, a reference scenario was developed by the National Research Centre for Economy [4], which is based on a "business as usual" macro scenario. Since the 2010 scenario emissions are high, it was defined, for Portugal, an intercalary scenario with emissions projections for 2005, in order to facilitate the implementation of measures and the accomplishment of 2010 targets. Besides that, two different scenarios (high and low) were also established, for each year (2005 and 2010), according to macroeconomic and sector-based indicators. The low scenario corresponds to a low growth of the Gross Domestic Product (GDP), in opposition to the high scenario that reflects a faster economic evolution, with a higher investment rate. Table I presents a comparison between total $\mathrm{SO}_{2}, \mathrm{NO}_{\mathrm{x}}, \mathrm{NMVOC}$ and $\mathrm{NH}_{3}$ emissions estimated for 2001 baseline year and 2005 and 2010 scenarios. Last revision of the NEC values is also presented [5]. 
Table 1: Comparison between the total emissions estimated for 2001 baseline year, 2005 and 2010 scenarios, and the national emissions ceilings for 2010 .

\begin{tabular}{|c|c|c|c|c|}
\hline (kt/year) & $\mathrm{SO}_{2}$ & $\mathrm{NO}_{\mathrm{x}}$ & $\mathrm{NMVOC}$ & $\mathrm{NH}_{3}$ \\
\hline Baseline year (2001) & 242 & 383 & 468 & 89 \\
\hline Low scenario 2005 & 231 & 274 & 240 & $? ?$ \\
\hline High scenario 2005 & 223 & 275 & 252 & $? ?$ \\
\hline Low scenario 2010 & 139 & 220 & 200 & 85 \\
\hline High scenario 2010 & 145 & 232 & 222 & 85 \\
\hline Emission ceilings 2010 & 160 & 250 & 180 & 90 \\
\hline
\end{tabular}

The scenarios established for 2005 allow a reduction of emissions, in relation to 2001 baseline, which is higher for NMVOC (about 50\%) and smaller for $\mathrm{SO}_{2}$ (only 5\%). Moreover, the reduction defined for 2010 scenarios is significantly large for all the above-mentioned pollutants ( 40-60\%). All pollutants emissions, with the exception of $\mathrm{NH}_{3}$, exceeded in 2001 and 2005, the national ceilings for 2010 (see Table 1). Nevertheless, the emission reductions projected for 2010 will be enough, for both scenarios (low and high) to accomplish the target values for $\mathrm{SO}_{2}$ and $\mathrm{NO}_{\mathrm{x}}$. This is not the case for the NMVOC, for which the reduction measures seems not sufficient to fulfil the NEC stated for this pollutant. An additional effort to reduce (by 10-20\%) these emissions is being planned, affecting mainly the domestic sector, public construction and the storage/distribution of fossil fuels [6]. Table 1 shows also that the difference between low and high scenario is not significant, for both 2005 and 2010 years, with a maximum variance of $10 \%$.

The contribution of each sector for the total emissions of $\mathrm{SO}_{2}, \mathrm{NO}_{\mathrm{x}}$ and NMVOC, for the baseline and future emission scenarios, is presented in Figures 1,2 and 3, respectively. The combustion activities, including transport and industrial processes, can be identified as the main sources of these gases.

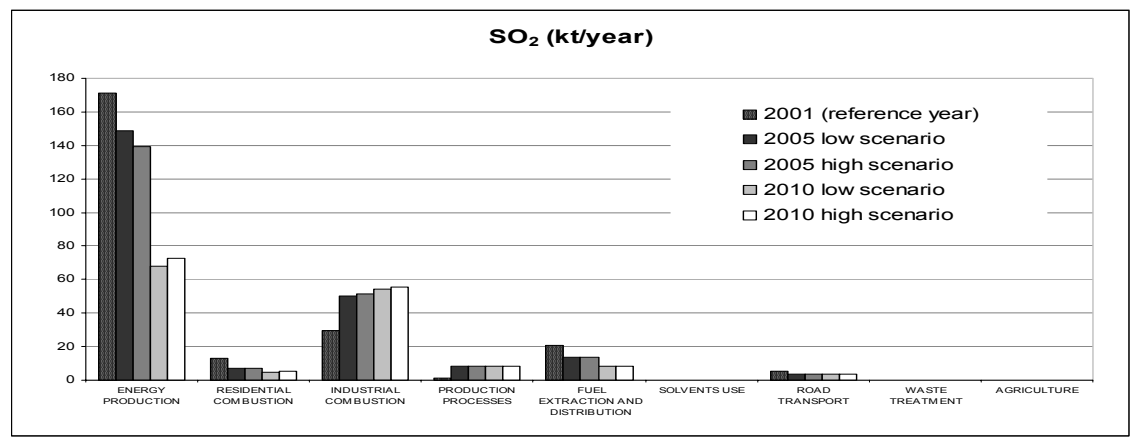

Figure 1: Comparison of $\mathrm{SO}_{2}$ emissions for the baseline year and the low/high scenarios for 2005 and 2010, by activity type. 
In the case of $\mathrm{SO}_{2}$ (Figure 1), almost all the sectors (exception to industry) will suffer emissions reduction. This reduction will be more pronounced in the energy production sector (the main contributor to $\mathrm{SO}_{2}$ emissions) and storage/distribution of fossil fuels.

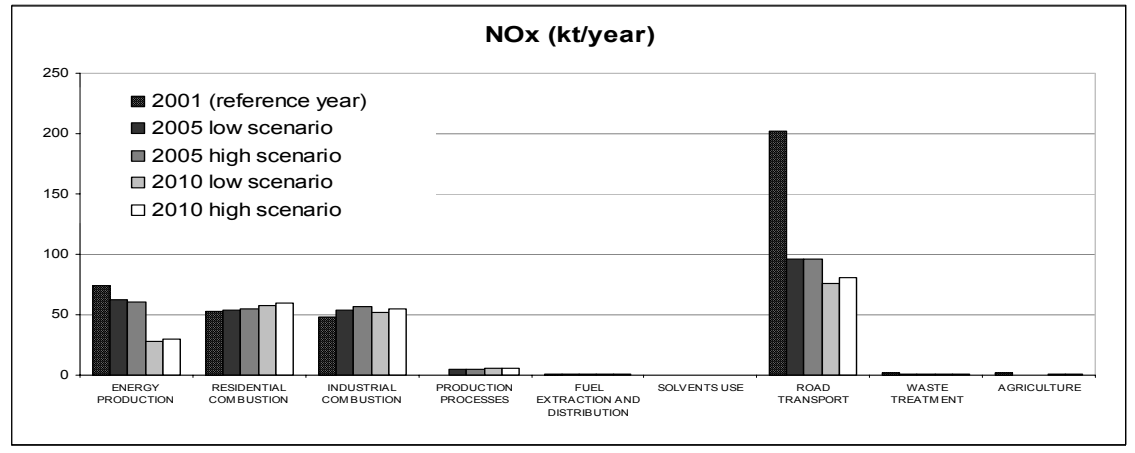

Figure 2: Comparison of $\mathrm{NO}_{\mathrm{x}}$ emissions for the baseline year and the low/high scenarios for 2005 and 2010 , by activity type.

Concerning $\mathrm{NO}_{\mathrm{x}}$ emissions (Figure 2), there will be an increase in combustion activities sectors but a significantly reduction in road transportation and energy production (the main contributor sectors), responsible for the decrease of the total emission data.

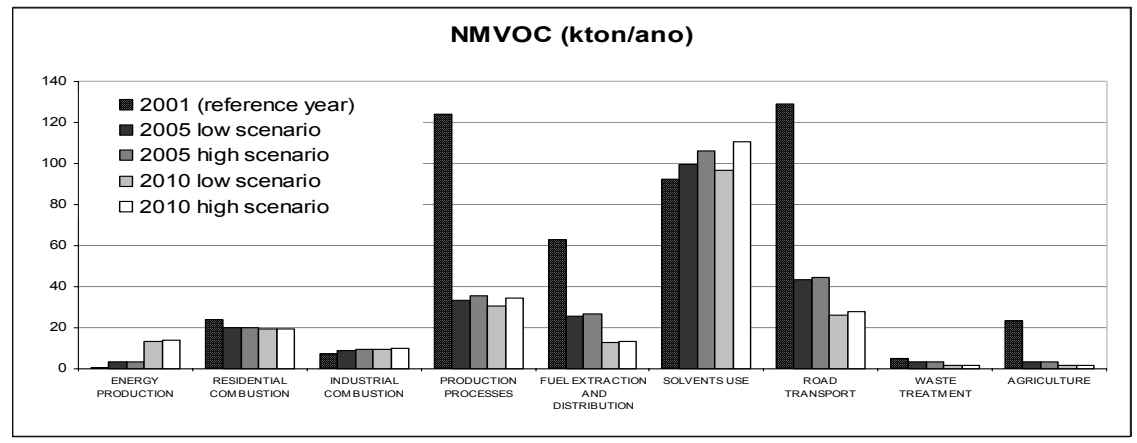

Figure 3: Comparison of NMVOC emissions for the baseline year and the low/high scenarios for 2005 and 2010 , by activity type.

With respect to NMVOC emissions, there are five principal pollutant activity sectors: industrial processes (including solvents use), storage/distribution of fossil fuels and road transport. For all these sectors (excluding solvents use) is foreseen a large emission reduction (50-60\%). This strategy for future scenarios will imply a reduction on the consumption of fossil fuels, probably induced by changes on fuel type or combustion process. However, it is expected an increase on NMVOC emissions, relatively to the 2001 baseline year, from energy 
production, industrial combustion and above all from solvents use. The diversity of emission sources (intrinsically and economically) turns particularly difficult and complex the definition of reduction politics, since it is not easy to identify a key group of activities responsible for a large percentage of NMVOC emissions and, simultaneously, with a high emission reduction potential.

In a global analysis, it seems that the most important emission reduction measures, planned for future scenarios, are focused on road transport activities, rather than industrial and residential combustion processes.

At last, it should be considered (and not forgotten) the high uncertainty level affecting all these future emissions estimation, that are derived by

- uncertainties on the 2001 baseline case and consequently projections for 2005 and 2010;

- uncertainties associated to the political instruments in force and the implementation of new ones;

- uncertainties associated to the estimation of the potential emission reduction of each measure.

\section{Air quality impact of the PTEN emissions scenarios}

In order to evaluate the impact of these emission reductions scenarios on air quality, numerical simulations with the CHIMERE model were performed over Continental Portugal, first for the 2001 baseline year and then compared with the 2005 and 2010 scenarios, using the same 2001 meteorological conditions.

CHIMERE is a 3D chemistry-transport model based on the integration of the continuity equation for the concentrations of several chemical species in each cell of a given grid [7] and has been used for several research applications, among which sensitivity to anthropogenic or biogenic emissions $[8,9]$, emission diagnostics [10] or air quality forecasting [11]. This numerical system was also already applied over Portugal for $2001[12,13]$, showing reasonable skills for ozone and other gas pollutants. The model version used here is primarily described in Schmidt et al [7] and further updates can be found in Vautard et al [10]. The meteorological input variables are taken from the European Centre for Medium-range Weather Forecast (ECMWF): 3D fields of horizontal wind, temperature, specific humidity, cloud liquid water content, and 2D fields of surface pressure, heat fluxes, $2 \mathrm{~m}$ temperature and cloud cover. They are linearly interpolated to the CHIMERE grid and linear time interpolation is also applied to obtain hourly values. Besides the meteorological input, the CHIMERE model needs boundary and initial conditions, emission data and the land-use and topography characterization. The national total emission data of each simulated year (2001, 2005 and 2010) were disaggregated according to a top-down methodology [12]. The model was applied first to a continental-scale (from $10.5 \mathrm{~W}$ to $22.5 \mathrm{E}$ and $35 \mathrm{~N}$ to $57.5 \mathrm{~N}$, see Figure $4 \mathrm{a}$ ) and then to Portugal (see Figure $4 \mathrm{~b}$ ), using the same physics and a simple one-way technique. The second simulation (Portugal domain) was performed with a horizontal domain of 290 $\mathrm{km} \times 580 \mathrm{~km}$ and a $10 \mathrm{~km}$ horizontal resolution and the vertical grid consisted in 6 hybrid sigma-pressure layers with a model top at $700 \mathrm{hPa}$. The top altitudes of 
the layers vary with time, but their approximate values are, from bottom to top: $50,250,600,1200,2000$ and $3000 \mathrm{~m}$.
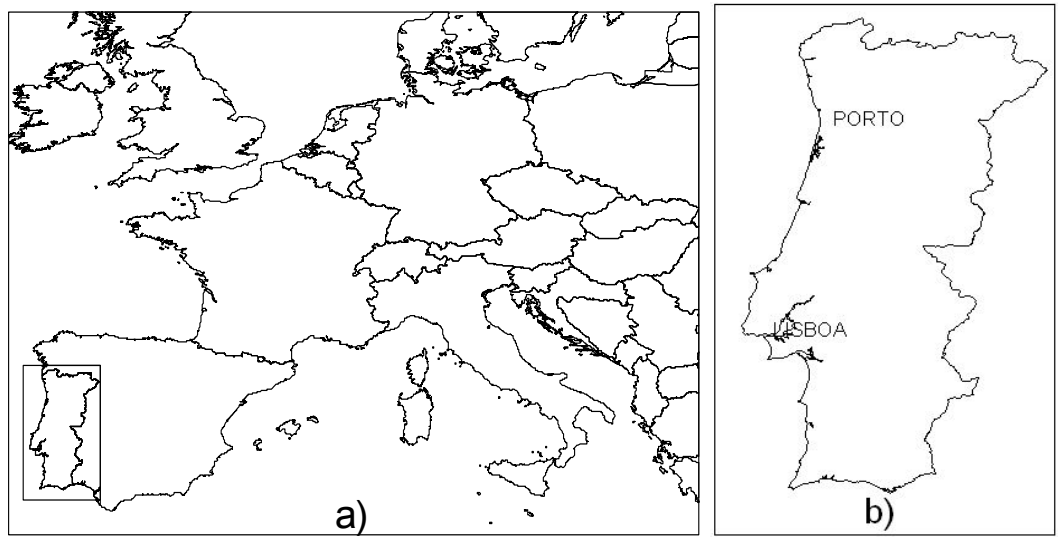

Figure 4: Geographical domains used by the CHIMERE model.

$\mathrm{SO}_{2}, \mathrm{NO}_{2}$ and $\mathrm{O}_{3}$ concentration values from the baseline 2001 simulation, and the years 2005 and 2010 simulations, were comparatively analysed taking into account the main air quality legislation parameters.

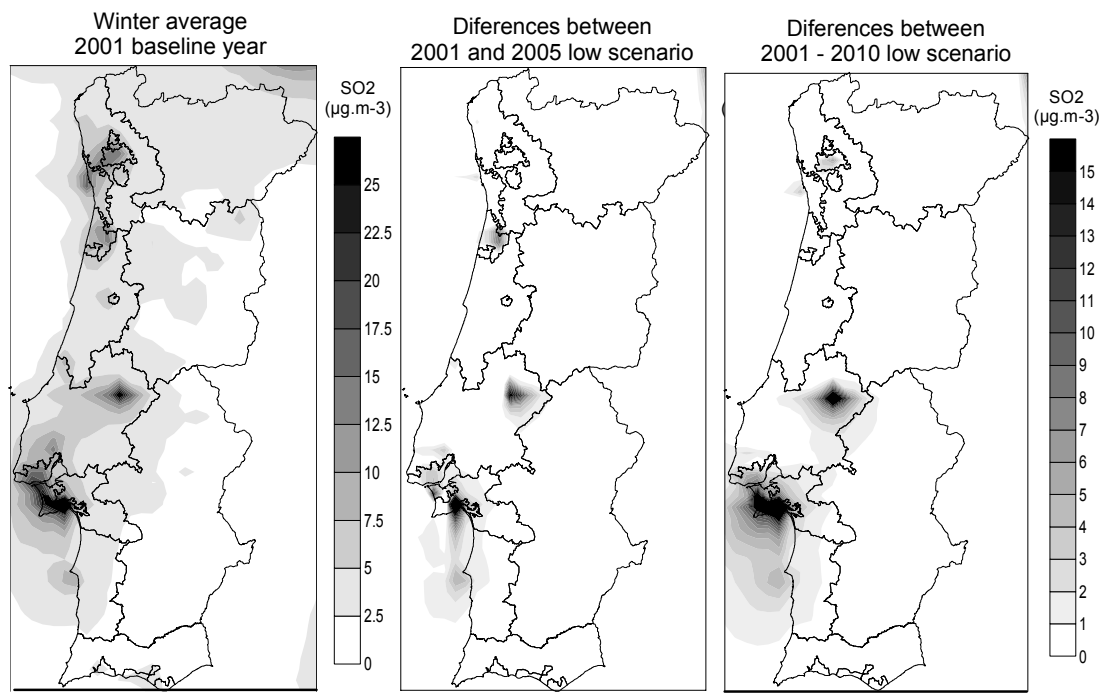

Figure 5: Modelling results for the $\mathrm{SO}_{2}$ winter average for 2001 and the respective differences between 2001 and 2005/2010 low scenarios. 


\subsection{Sulphur dioxide}

Figure 5 presents the $\mathrm{SO}_{2}$ winter averaged concentration values for the baseline year and the concentration differences between 2001 and 2005, and 2001 and 2010 scenarios.

The modelling $\mathrm{SO}_{2}$ results (Figure 5) show a significant reduction on the maximum winter averages expected for 2005 and 2010, comparatively to the baseline case (2001). This is more notorious for the 2010 scenario, where reductions are often higher than $15 \mu \mathrm{g} . \mathrm{m}^{-3}$. The major decreases were obtained over the main industrial areas of Portugal, namely in the South of Lisbon (Península de Setúbal) and in the centre of Portugal (Pego). The abatement strategies defined for 2010 seem to be sufficiently efficient to fulfil the legislated limit values, at least in what concerns the winter average parameter for vegetation protection $\left(20 \mu \mathrm{g} \cdot \mathrm{m}^{-3}\right)$.

\subsection{Nitrous dioxide}

Figure 6 presents the modelling results obtained for the health protection limit value of $\mathrm{NO}_{2}$, for 2001, and the differences between 2005 and 2010 low scenarios and the baseline for the same parameter.
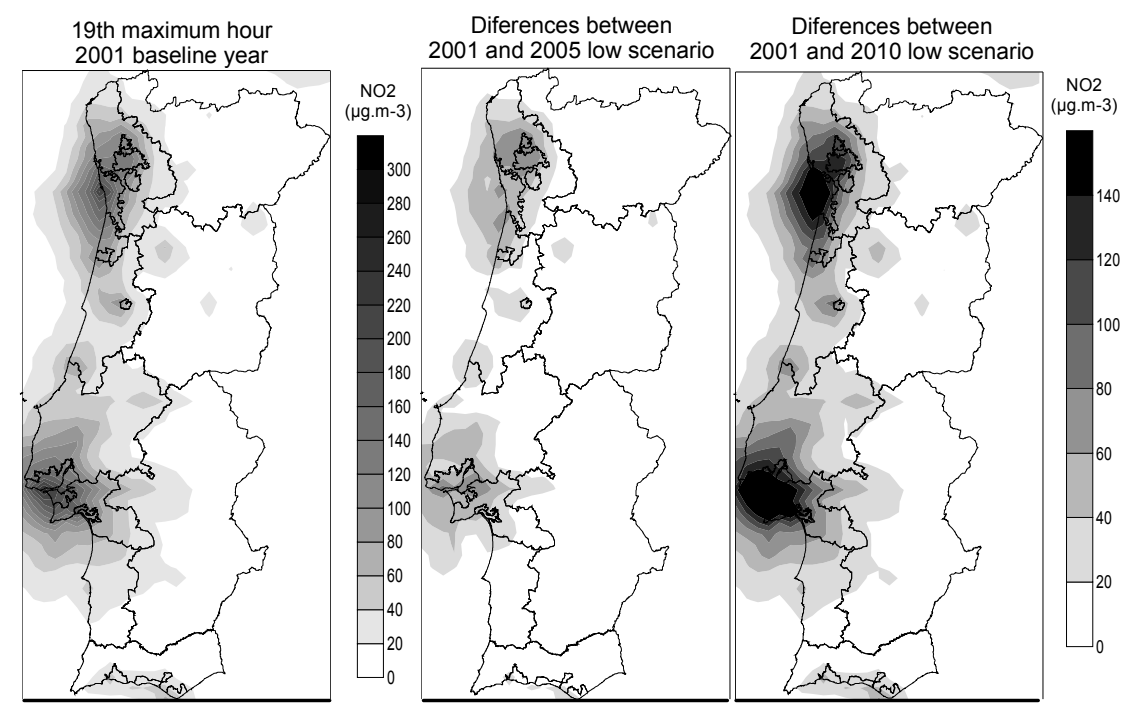

Figure 6: Modelling results for the protection health hourly limit of $\mathrm{NO}_{2}$ for 2001 and the respective differences between 2001 and 2005/2010 low scenarios.

In what concerns $\mathrm{NO}_{2}$, the air quality improves significantly with the reduction measures planned for 2005 and especially for 2010. The differences between this last scenario and the baseline year reach $50 \%$ over the main urban centres (Porto and Lisbon) and at the same time the most problematic areas in 
terms of $\mathrm{NO}_{2}$ pollution. This suggests that in 2010 no exceedings to the hourly protection health limit value for this pollutant will be expected anymore.

\subsection{Ozone}

Since ozone is a very critical photochemical pollutant, two different approaches were used to analyse the modelling results. Table 2 quantifies the number of exceedances to the limit values (information threshold and AOT40) simulated for the baseline case and for the 2005 and 2010 scenarios. The difference obtained between the number of hourly averaged values higher than the information threshold for 2001 and 2005 scenarios is quite significant (reduction of $60 \%$ ), but is considerably superior for 2010 (reduction of $90 \%$ ). This is even higher when the number of exceedings of the Accumulated Ozone Threshold are analysed. Besides that, results confirm the small difference between the low and high simulation scenarios defined for each future year (2005 and 2010).

Table 2: Ozone exceedances of the information threshold $\left(180 \mu \mathrm{g} \cdot \mathrm{m}^{-3}\right)$ and AOT40 (18 $\left.000 \mu \mathrm{g} . \mathrm{m}^{-3} . \mathrm{h}\right)$, for 2001, 2005 and 2010 simulation years.

\begin{tabular}{|l|c|c|c|c|c|}
\hline & 2001 & \multicolumn{2}{|c|}{2005} & \multicolumn{2}{c|}{2010} \\
\hline & $\begin{array}{c}\text { baseline } \\
\text { year }\end{array}$ & $\begin{array}{c}\text { high } \\
\text { scenario }\end{array}$ & $\begin{array}{c}\text { low } \\
\text { scenario }\end{array}$ & $\begin{array}{c}\text { high } \\
\text { scenario }\end{array}$ & $\begin{array}{c}\text { low } \\
\text { scenario }\end{array}$ \\
\hline $\begin{array}{l}\text { Number of grid cells with } \mathrm{O}_{3} \\
\text { concentration }>180 \mu \mathrm{g} \cdot \mathrm{m}^{-3}\end{array}$ & 668 & 269 & 266 & 72 & 63 \\
\hline $\begin{array}{l}\text { Number of grid cells with } \\
\text { AOT40 }>18000 \mu \mathrm{g} \cdot \mathrm{m}^{-3} . \mathrm{h}\end{array}$ & 133 & 11 & 8 & 2 & 0 \\
\hline
\end{tabular}
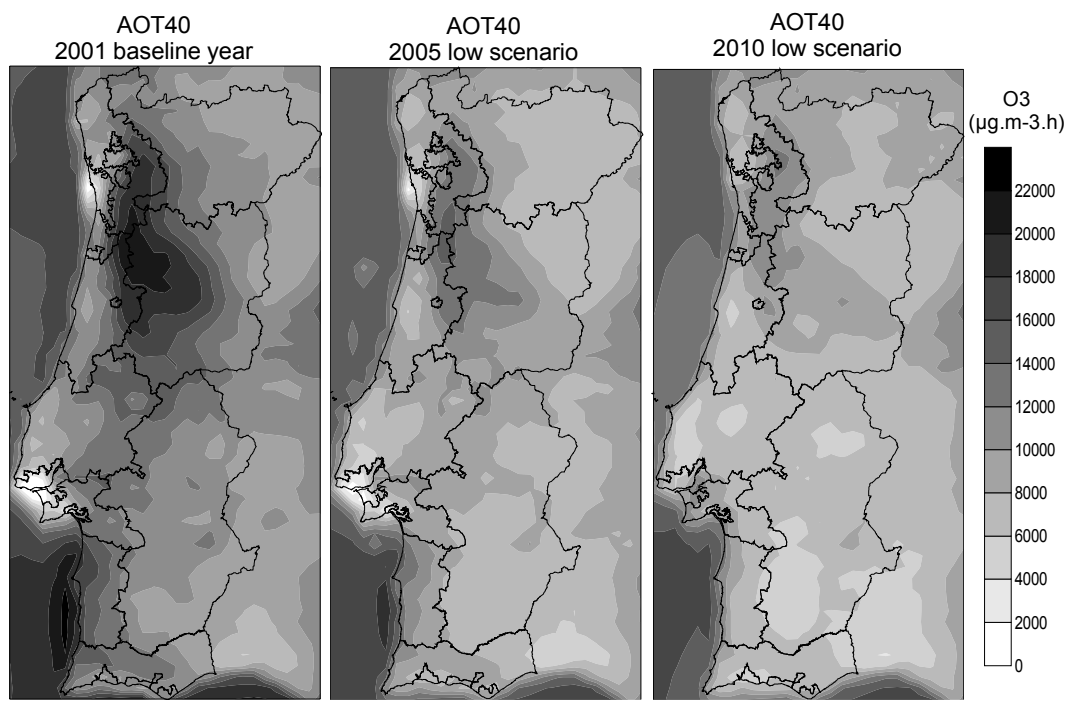

Figure 7: $\quad$ Modelling results for the ozone AOT40 for 2001 baseline case and the low scenarios of 2005 and 2010. 
In Figure 7 is presented the spatial distribution obtained for the AOT40 for the baseline case and the low future scenarios. The improvement on air quality is confirmed with the significant differentials obtained for 2005 and 2010 scenarios. The fulfilment of the AOT40 would be guaranteed with the 2010 scenario implementation, confirming the Table 2 results. Nevertheless, this improvement is not spatially uniform and visible on the entire domain. In fact, over the two main urban centers (Porto and Lisbon) the concentration differences are null or even negative. According to the photochemistry of tropospheric ozone [14] the decrease on ozone precursor emissions could be the explanation for the increase of ozone levels at these urban areas.

\section{Summary and conclusions}

In order to evaluate the impact on air quality of the NEC scenarios, numerical simulations were performed with the CHIMERE air quality model, for the 2001 baseline year and future scenarios for 2005 and 2010. For all the simulations the same meteorological conditions were used as input (2001 year), and the respective national emission inventory spatially disaggregated. The results were analysed for the most critical gas pollutants, namely $\mathrm{SO}_{2}, \mathrm{NO}_{2}$ and $\mathrm{O}_{3}$, taking as reference current legislation. The results show a significant improvement on the air quality with the application of the future scenarios, and a complete fulfilment of the limit and threshold values would be achieved on 2010 year. Besides that, the low and high scenarios do not show significant differences for 2005, as well as for 2010 year. The improvement on air quality is clear over the main industrial areas concerning the $\mathrm{SO}_{2}$, and more significant over the urban centers, in respect to $\mathrm{NO}_{2}$. In what concerns the ozone, this improvement will be higher in the centre part of Portugal, and less at the cities of Porto and Lisbon. In summary, modelling results confirm the efficiency of the emissions reduction strategies defined by the NEC programme for 2010 within the NEC agreement under the Gothenburg Protocol.

\section{Acknowledgements}

The authors would like to thanks to the Portuguese Ministério da Ciência, Inovação e Ensino Superior, for the $\mathrm{PhD}$ grant of $\mathrm{A}$. Monteiro (SFRH/BD/10922/2002). The authors are also grateful to the Portuguese Institute for the Environment for financing and giving access to the NEC emissions scenarios data.

\section{References}

[1] Directive 2001/81/EC on national emissions ceilings for certain atmospheric pollutants. 
[2] UNECE-United Nations Economic Commission for Europe,1999. Protocol to Abate Acidification, Eutrophication and Ground-level Ozone. Available at www.unece.org/env/lrtap/multi h1.htm

[3] Amann M. The RAINS model. Documentation of the model approach prepared for the RAINS peer review, February 2004: www.iiasa.ac.at/rains/

[4] IA - Instituto do Ambiente. Programa para os Tectos de Emissão Nacional - Estudos de base: Cenário de cumprimento, 2004: www.iambiente.pt

[5] IA - Instituto do Ambiente. Programa para os Tectos de Emissão Nacional - Estudos de base: Cenário de referência, 2004: www.iambiente.pt

[6] IA - Instituto do Ambiente. Programa para os Tectos de Emissão Nacional - Estudos de Base: Medidas para o controlo das emissões nacionais de COVNM, 2004: www.iambiente.pt

[7] Schmidt, H., Derognat, C., Vautard, R., and Beekmann, M. A comparison of simulated and observed ozone mixing ratios for the summer of 1998 in Western Europe. Atmospheric Environment, 35, pp. 2449-2461, 2001.

[8] Beekmann, M. and Derognat, C. Monte Carlo uncertainty analysis of a regional-scale transport chemistry model constrained by measurements from the Atmospheric Pollution Over the Paris Area (ESQUIF) campaign. J. Geophys. Res., 108, D17, p. 8559, 2003.

[9] Derognat, C., Beekmann, M., Baeumle, M., Martin, D, and Schmidt, H. Effect of biogenic volatile organic compound emissions on tropospheric chemistry during the Atmospheric Pollution Over the (ESQUIF) campaign in the Ile-de-France region. J. Geophys. Res., 108, D17, p 8560, 2003.

[10] Vautard, R. Martin, D, Beekmann, M. Drobinski, P., Friedrich, R., Jaubertie, A., Kley, D., Lattuati, M., Moral, P., Neininger, B., Theloke, J. Paris emission inventory diagnostics from ESQUIF airborne measurements and a chemistry transport model, J. Geophys. Res., 108, D17, p. 8564, 2003.

[11] Vautard, R., Beekmann, M., Roux, J. and Gombert, D. Validation of a deterministic forecasting system for the ozone concentrations over the Paris area. Atmospheric Environment, 35, pp. 2449-2461, 2000.

[12] Monteiro, A., Vautard, R., Borrego, C. and Miranda, A. I. Long-term simulations of photo oxidant pollution over Portugal using the CHIMERE model. Atmospheric Environment, 39, pp. 3089-3101, 2005a.

[13] Monteiro, A., Vautard, R., Lopes, M., Miranda, A.I. and Borrego, C. Air Pollution Forecast in Portugal: a demand from the new Air Quality Framework Directive. Int. J. of Env. and Pollution, 25, N 2, pp 4-15, $2005 \mathrm{~b}$.

[14] Seinfeld, J.H., Pandis, S.N. Atmospheric Chemistry and Physics. Wiley, New York. 